\title{
Land development policy as related to real estate influenced by railway noise in the context of allowable indicators that have been recently modified in Poland
}

\begin{abstract}
The paper deals with the problem of rail noise pollution in cities in the context of legal amendments. This aspect is often neglected in the process of spatial planning. The authors were motivated to undertake this analysis both by legal changes permitting higher levels of acceptable noise thresholds, which were introduced and legalised in October 2012, and by the intensified levels of investment in areas neighbouring railways. On selected examples of residential areas in Warsaw, Poland (the city districts of Ursus, Białołęka and Ursynów), relevant land development sites were analysed against the course of isophones showing permissible noise levels. The analysis was based on data taken from acoustic maps for Warsaw from 2012 and 2017, planning studies, the Topographic Objects Database (BDOT10k) and the current state of land development. Using ArcGis software, 22 features, three study areas, and corresponding quantitative indicators were assessed. The authors presented the level of railway noise pollution set against the general spatial development. The analysis demonstrated that the changes in legislation have resulted in the "acoustic release" of land near railways; i.e., in these areas new, lessrestrictive regulations on noise pollution have become permissible. In turn, the number of buildings that were considered at risk of noise pollution before 2012 has fallen.

The aforementioned regulatory changes may unfavourably impact residential areas neighbouring railways and this has even provoked a wider discussion at the European Union level.
\end{abstract}

Keywords

Rail noise risk $\cdot \mathrm{L}_{\mathrm{N}}$ and $\mathrm{L}_{\mathrm{DWN}}$ indicators $\cdot$ spatial planning $\cdot$ spatial land development

(C) University of Warsaw - Faculty of Geography and Regional Studies

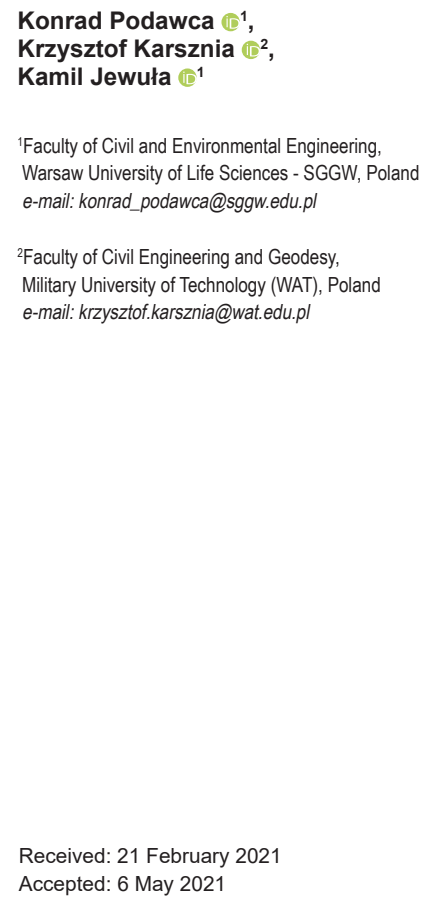

Konrad Podawca $\mathbb{C}^{1}$, Krzysztof Karsznia $\mathbb{C}^{2}$, Kamil Jewuła $\mathbb{C}^{1}$

${ }^{1}$ Faculty of Civil and Environmental Engineering, Warsaw University of Life Sciences - SGGW, Poland e-mail: konrad_podawca@sggw.edu.pl

${ }^{2}$ Faculty of Civil Engineering and Geodesy, Military University of Technology (WAT), Poland e-mail: krzysztof.karsznia@wat.edu.pl

Received: 21 February 2021

Accepted: 6 May 2021

Introduction

Ever larger numbers of people are living in cities. The dynamic urbanisation that began in the mid-nineteenth century was mainly driven by industrialisation. These days, it is caused by the desire for a better quality of life access to services and entertainment and, in general, improved working conditions and remuneration. Over $55 \%$ of the world's population and almost $75 \%$ of Europeans live in cities, including $60 \%$ of Poles (World Urbanization Prospects 2018). The Polish capital, Warsaw, is a good example of the considerable changes to city populations over the last 70 years. In 1951, Warsaw had 803,800 inhabitants. By 1975, 25 years later, this had risen to $1,463,400$. Over the next 25 years, this number increased again to $1,671,700$ and, by the beginning of 2019, Warsaw's population had reached almost $1,778,000$ inhabitants (Statistical Office in Warszawa 2021). The progressive urbanisation of cities continuously reduces the amount of available land for investment. The characteristics of urbanisation and suburbanisation have become the subject of both global and local (in our case, Polish) research on different levels (Degórska 2012; ed. Śleszyński 2012; Spórna 2018; Podawca \& Mrozik 2019; Podawca et al. 2019), with particular regard to the uncontrolled development of other large cities such as, for example, Barcelona (Roca et al.
2004), Rome (Di Zio \& Montanari 2010), Seoul (Woo 2014), Moscow (Brade \& Rudolph 2004) and metropolitan areas in the USA (Huang et al. 2017). The huge demand for apartments and services is driving the search for new sites, even if the location is not environmentally favourable for residential purposes; e.g., areas near railway lines that are subject to intense investment pressure. The landscape here currently differs both aesthetically and in development character from the surrounding regions (Ryś 2015). However, proper spatial planning of areas near railway lines should include consideration of their actual impact on the environment. Noise is the primary and most substantial risk (Makosz 2015; Podawca \& Staniszewski 2019; Preis et al. 2019). According to reports from EU member states received by the European Environment Agency in 2010, railway noise during the day was a problem for about 12 million EU inhabitants who were exposed to noise levels above 55dB (EU Directive 2002/49/WE) and, at night, for about 9 million people, who were exposed to noise levels exceeding $50 \mathrm{~dB}$ (Clausen et al. 2012). Therefore, the decision to site new residential and service buildings close to sources of railway noise should be preceded by appropriate acoustic analysis. Unfortunately, the subject literature contains many more studies on the impact of 
road noise (Popławska et al. 2012; Profaska 2012; Podawca 2014), or even noise from household devices (Zagubień \& Wolniewicz 2017) than on the impact of noise pollution from railway infrastructure (Deja \& Kopeć 2016; Podawca \& Staniszewski 2019). The issue of noise pollution - including railway noise - the methodology for studying it, and the visualisation guidelines for hazard maps are presented in Felcyn et al. 2018. That paper presents a proposal for a methodology of data collection and presentation based on the example of the city of Poznan (Poland). In that case, the issue of noise pollution from railway lines was studied, in particular in the context of European standards - the Environmental Noise Directive (END); here, projects called 'Noise Action Plans' (NAP) deserve special attention.

The level at which railway noise causes a (negative) human response is estimated to be $42 \mathrm{~dB}$ (Miedema \& Oudshoorn 2001; Petersen \& Waye 2007). For night time noise, research shows that adverse changes in sleep quality start to appear when the noise level exceeds $30 \mathrm{~dB}$. Such sound intensity may cause waking up (Sobotova 2010). Sleeping at the sound level of 55-60dB does not provide the desired quality of rest and almost certainly leads to waking up (Sobotova 2010; Berregard \& Stansfeld 2014). The World Health Organisation (WHO) estimates that $40 \mathrm{~dB}$ of noise outside buildings at night is the upper limit at which people are still protected against the harmful effects of noise on sleep and health (WHO 2009).

Additionally, some reports have appeared suggesting even that the risk of heart attacks slightly increases at noise levels from $30 \mathrm{~dB}$ to $55 \mathrm{~dB}$ at night, (Passchier-Vermeer \& Passchier 2000). Finnish studies, performed on a population of 7019 adults, showed that people with greater levels of fear and those suffering from anxiety might experience sleep disorders at levels $5 \mathrm{~dB}$ lower than the socalled "ordinary" population, for whom such disturbances appear at night-time sounds of 50dB (Halonen et al. 2012). Environmental noise increases the risk of hypertension when exposed to levels above $65 \mathrm{~dB}$. The risk of hypertension increases with higher decibels (Jarup et al. 2008; Pawlas 2015). Short-term surveys show that, for each $10 \mathrm{~dB}$ increase in the volume of sound from the surrounding environment, one can observe an increase of $1 \mathrm{~mm}$ $\mathrm{Hg}(95 \% \mathrm{Cl}: 0.3$ to $1.6, \mathrm{p}=0.004)$ in systolic pressure and 0.6 $\mathrm{mm} \mathrm{Hg}(95 \% \mathrm{Cl}: 0.1$ to $1.2, \mathrm{p}=0.025)$ in diastolic pressure of (Babisch et al. 2009).

Noise-prevention approaches combine all required actions aimed at improving the acoustic climate in areas at risk (Vogiatzis \& Remy 2017). In general, noise-protection policy deals with two types of impact: reducing noise emitted by infrastructure facilities, (as represented by relevant indicators), and reducing the number of people who are exposed to high levels of environmental noise (as defined by existing legislation), i.e., limiting the size of residential areas.

It should be added that noise level is one of the critical factors taken into account when deciding where to live (Zwierzchowska 2017). Along with other specific parameters of a given area, such as land cover and land-use types, and other anthropogenic elements, this falls under the comprehensive concept of Ecosystem Services (ES), illustrating the potential of a particular area. ES evaluation results set the tone for the development of urban space, e.gl, towards a corresponding increase in the share of green areas. To underline this point, reference can be made to publications 2008a and 2008b by Beim and Tölle. They show that the main motivation for deciding to leave a city is a combination of multiple negative factors, among which heavy traffic and even the age and technical condition of buildings play an essential role (Beim \& Tölle 2008b). Factors such as these, including noise levels, form one component of a larger puzzle that defines quality of life, shapes the main directions in spatial planning (Von der Dunk, 2011), and determines property values (Simons \& Jaouhari 2004). Unique indicators (relevant for the EU - including Poland) showing the noise levels affecting people are presented in detail in Wrótny and Bohatkiewicz 2020, and Podawca and Karpiński 2021. The authors studied the impact of railway noise on quality of life with respect to acoustic maps and European Union Directive 2002/49/EC. It is particularly noticeable in this context that the relevant legal amendments concerning noise indicators, approved in Poland after 2012, may not fully meet the requirements of said Directive. To clarify these ambiguities, the new noise pollution standards (in the case of this article referring to railway noise) have been discussed extensively by the European Commission (EC Press release from 18 February 2021). What is more, one should mention crucial regulations of the EC which aim to reduce the noise level of rolling stock which runs through urbanized areas e.g., Commission Implementing Regulation (EU) 2015/429 of 13 March 2015, or Commission Implementing Regulation (EU) 2019/774 of 16 May 2019). Therefore, it can be concluded that the issue of data modelling aimed at the practical management of noise pollution is a universal one and is of particular relevance to residential areas located close to railway lines.

\section{Research problem}

The aim of the performed analysis was to show the effects of the changed legislation to increase permissible noise levels caused by railway lines (which came into force on 1 October 2012) on spatial development. As the central part of the scientific objective, the following research tasks (RT) were formulated:

- demonstration of the changes which took place between 2012 and 2017 in the "acoustic climate" in selected areas RT1;

- presentation of the railway noise hazard in the analysed regions, according to the regulations on permissible noise levels from 2007 and 2012, based on a developed list of 22 superficial and quantitative features related to this hazard RT2;

differential analysis of phenomena that appear while doing spatial research on these areas due to the reduction of permissible railway noise levels - RT3.

The research areas chosen for analysis were based on the following selection criteria:

the presence of an active railway line, through which rail transportation is conducted at national or regional level,

- the existence of functions and objects within the areas which, following the applicable legal regulations, are classified as areas exposed to noise and, hence, are subject to permissible levels of railway noise,

- $\quad$ variation in the degree of urbanisation in the area.

To investigate the above-mentioned problems, we selected three areas located in Warsaw, Poland; namely the city districts of Ursus, Białołęka and Ursynów (Fig. 1).

The selection of test sites was driven by their slightly different nature, as well as their location in the territorial area of Warsaw. It should be mentioned that no investments related to the reconstruction of railway lines or other modernisation activities that could quickly change the noise parameters in the immediate vicinity have been carried out in the chosen areas. In order to draw reliable conclusions, we should add that the study areas lack noise protection screens (Ursynów, Białołęka), or only have sections of them installed along the railway lines (Ursus).

Each study area can be easily identified using the 'Geoportal' public map portal, authorised and maintained by the head office of the Polish Office of Geodesy and Cartography; details can be found at www.geoportal.gov.pl. Moreover, the areas can also be localised using a publicly-available, interactive map of railway lines, published by Polish State Railways (http://mapa.plk-sa.pl). 


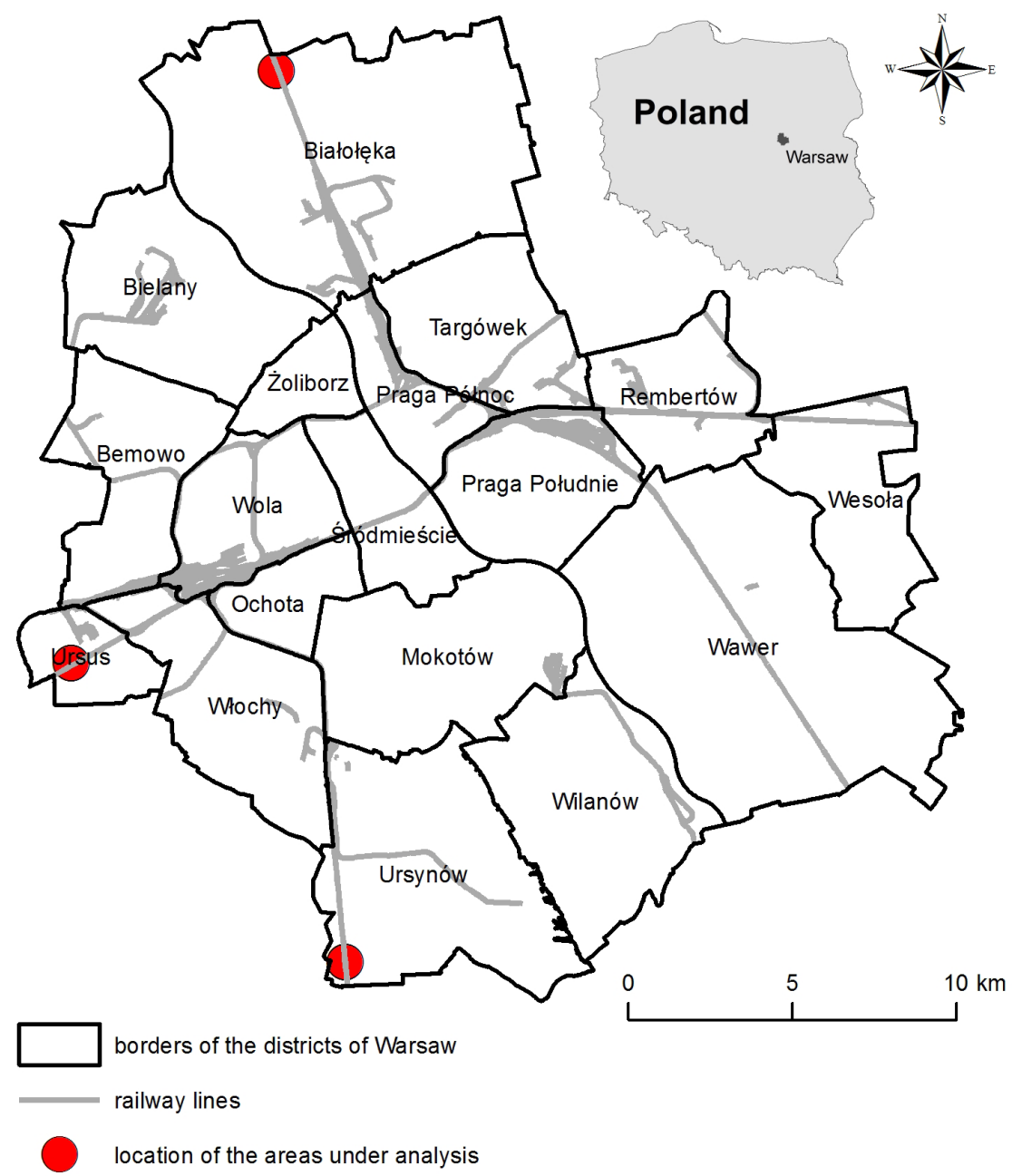

Figure 1 Location of the analysed areas, Warsaw, Poland Source: own elaboration

The first area analysed is in Ursus (Area I), with the centroid represented by geographic coordinates: N52 ${ }^{\circ} 11^{\prime} 45^{\prime \prime}$, E20 $23^{\circ} 3^{\prime \prime}$. The area is delimited by the cadastral units (territorial entity for settlements in Poland) 2-09-06 - "Piastów" to the West, 2-11-09, 2-11-02 to the South, 2-09-08 to the East and 2-09-07 and 2-0906 to the North. The analysed area covers 49.65 ha, and the railway lines take up 2.82 ha. Warszawa Ursus - Niedźwiadek railway station is located within this area, and the E65 railway line (route $\mathrm{VI}$ ) to Katowice runs through here as well. The railway line is one of the main international routes, with permissible traffic speeds of $60 \mathrm{~km} / \mathrm{h}$ to $120 \mathrm{~km} / \mathrm{h}$ (with four rail gauges for different purposes).

The second study area is located in Białołęka (Area II), with the centroid represented by geographic coordinates: $\mathrm{N} 52^{\circ} 19^{\prime} 45^{\prime \prime}, \mathrm{E} 21^{\circ} 0^{\prime} 30^{\prime \prime}$. The area is delimited by the cadastral units $4-02-06,4-02-11$ to the West; 4-02-17, 4-17-08 to the South, 4-17-02, 4-17-06 to the East and 4-02-25 and the border of the Jabłonna municipality to the North. The analysed area covers 65.65 ha, including railway area of 2.77 ha. The railway line to Gdańsk runs through the district and the Warszawa Choszczówka railway station is situated here. The railway line is one of the main high-speed routes with permissible traffic speeds of up to $160 \mathrm{~km} / \mathrm{h}$.
The third area analysed is located in Ursynów (Area III), with the centroid represented by geographic coordinates: N52 $09^{\prime} 00^{\prime \prime}$, $\mathrm{E} 21^{\circ} 02^{\prime} 43^{\prime \prime}$. The area is delimited by cadastral units 1-09-60 "Zgorzała" to the West, 1-09-69 - "Mysiadło" to the South, 0109-70 to the East and units 01-09-57 and 01-09-55 to the North. The total study area covers 125.14 ha. In this case, the area covered by the railway is 2.84 ha, and the main railway line runs to Kraków. The railway track is also a main high-speed route with permissible traffic speeds of up to $160 \mathrm{~km} / \mathrm{h}$.

\section{Methods}

Due to the nature of the principal problem and the research methodology, the analysis was performed as a case study. The case study has become the prevalent analytical method in architecture and urban planning.

To proceed with the RT1 research task, we used acoustic maps for Warsaw from the years 2012 and 2017, produced digitally in the Polish national 'PUWG 2000' coordinate system by the publishing houses "BMTcom", "SVANTEK" and "PVO" for the office of the Mayor of the Capital City of Warsaw. We used ArcGIS software to overlay the course of individual isophones on the map of each research area. Areas exposed to railway noise of different levels were determined in relation to the railway line terrains. 
MISCELLANEA GEOGRAPHICA - REGIONAL STUDIES ON DEVELOPMENT

Vol. $25 \cdot$ No. $3 \cdot 2021 \cdot$ pp. 155-168 • ISSN: 2084-6118 • DOI: 10.2478/mgrsd-2020-0062

Table 1. Analysis indicators

\begin{tabular}{|c|c|c|}
\hline $\begin{array}{l}\text { Indicator } \\
\text { name }\end{array}$ & $\begin{array}{l}\text { Indicator } \\
\text { symbol }\end{array}$ & Indicator formula \\
\hline $\begin{array}{l}\text { „Acoustic } \\
\text { release" - } \\
\text { Night }\end{array}$ & $W_{U} A_{L N}$ & $\frac{F_{L N \rightarrow 50 d B}-F_{L N \rightarrow 59 d B}}{F_{L N \rightarrow 50 d B}}$ \\
\hline \multirow{2}{*}{$\begin{array}{l}\text { “Acoustic } \\
\text { release” - Day- } \\
\text { Dawn-Night }\end{array}$} & $W_{1} \cup A_{L D W N}$ & $\frac{F_{L D W N \rightarrow 55 d B}-F_{L D W N \rightarrow 64 d B}}{F_{L D W N \rightarrow 55 d B}}$ \\
\hline & $\mathrm{W}_{2} \mathrm{UA}_{\mathrm{LDWN}}$ & $\frac{F_{L D W N \rightarrow 60 d B}-F_{L D W N \rightarrow 68 d B}}{F_{L D W N \rightarrow 60 d B}}$ \\
\hline $\begin{array}{c}\text { "Acoustic- } \\
\text { functional } \\
\text { release"- Night }\end{array}$ & WUFA $_{L N}$ & $\frac{F T U_{L N \rightarrow 50 d B}-F T U_{L N \rightarrow 59 d B}}{F T U_{L N \rightarrow 50 d B}}$ \\
\hline \multirow{2}{*}{$\begin{array}{l}\text { "Acoustic- } \\
\text { functional } \\
\text { release" - Day- } \\
\text { Dawn-Night }\end{array}$} & $\mathrm{W}_{1} \mathrm{UFA}_{\mathrm{LDWN}}$ & $\frac{F T U_{L D W N \rightarrow 55 d B}-F T U_{L D W N \rightarrow 64 d B}}{F T U_{L D W N \rightarrow 55 d B}}$ \\
\hline & $\mathrm{W}_{2} \mathrm{UFA}_{\mathrm{LDWN}}$ & $\frac{F T U_{L D W N \rightarrow 60 d B}-F T U_{L D W N \rightarrow 68 d B}}{F T U_{L D W N \rightarrow 60 d B}}$ \\
\hline $\begin{array}{l}\text { "Construction- } \\
\text { acoustic" - } \\
\text { General/Night }\end{array}$ & $W_{B A}$ & $\frac{L B_{L N \rightarrow 50 d B}-L B_{L N \rightarrow 59 d B}}{L B_{L N \rightarrow 50 d B}}$ \\
\hline \multirow{2}{*}{$\begin{array}{l}\text { "Construction- } \\
\text { acoustic" - } \\
\text { General/Day- } \\
\text { Dawn-Night }\end{array}$} & $\mathrm{W}_{1} \mathrm{BA}_{\mathrm{LDWN}}$ & $\frac{L B_{L D W N \rightarrow 55 d B}-L B_{L D W N \rightarrow 64 d B}}{L B_{L D W N \rightarrow 55 d B}}$ \\
\hline & $\mathrm{W}_{2} \mathrm{BA}_{\mathrm{LDWN}}$ & $\frac{L B_{L D W N \rightarrow 60 d B}-L B_{L D W N \rightarrow 68 d B}}{L B_{L D W N \rightarrow 60 d B}}$ \\
\hline
\end{tabular}

\section{Source: own elaboration}

As a result, a spatially-oriented map showing deterioration or improvement of the acoustic climate was obtained.

The implementation of task RT2, as a detailed characteristic of railway noise risk, was based on the analysis of 22 features already used in the subject literature (Podawca \& Staniszewski 2019; Podawca \& Karpiński 2021). These features (all abbreviations and marks in line with domestic terminology officially accepted in the legal regulations) include:

- the terrain surface from the border of the railway area to the range of the isophone $L_{N} 50 \mathrm{~dB}$ for night time marked as $F_{L N \rightarrow 50 \mathrm{~dB}}$ (feature No. 1) and to the range of the isophone $L_{N}$ $59 \mathrm{~dB}$ for night time marked as $\mathrm{F}_{\mathrm{LN} \rightarrow 59 \mathrm{~dB}}$ (feature No. 2);

- the terrain surface from the border of the railway area to the range of the isophone $L_{D W N} 55 d B$ for the day-eveningnight time, marked as $\mathrm{F}_{\mathrm{LDWN} \rightarrow 55 \mathrm{~dB}}$ (feature No. 3), to the range of the isophone $L_{D W N} 60 \mathrm{~dB}$ for the day-evening-night time, marked as $F_{L D W N \rightarrow 60 d B}$ (feature No. 4), to the range of the $L_{D W N}$ isophones $64 \mathrm{~dB}$ in the day-evening-night time, marked as $F_{L D W N \rightarrow 64 d B}$ (feature No. 5), to the range of the $L_{D W N}$ isophone $68 \mathrm{~dB}$ for the day-evening-night time, marked as $F_{\text {, }}$ (feature number 6);

- the number of buildings exposed to above-normal noise situated within the $L_{N} 50 \mathrm{~dB}$ isophone at night time according to the regulations from 2007, marked as LB $_{\rightarrow 50 \text { dBLN }}$ (feature No. 7 ), the number of buildings located within the isophone
$L_{N} 59 d B$ at night time according to the rules from 2012, marked as $L B_{L N \rightarrow 59 d B}$ (feature No. 8), the number of buildings located within the isophone $L_{D W N} 55 \mathrm{~dB}$ in the day-eveningnight time according to the regulations from 2007, marked as $L_{\mathrm{LDWN} \rightarrow 55 \mathrm{~dB}}$ (feature No. 9), the number of buildings located within the isophone $L_{D W N} 60 d B$ in the day-eveningnight time according to the rules from 2007, marked as $\mathrm{LB}_{\mathrm{LDWN} \rightarrow 60 \mathrm{~dB}}$ (feature No. 11), and the number of buildings located within the $L_{D W N} 68 d B$ isophone in the day-eveningnight time according to the rules of 2012, marked as $\mathrm{LB}_{\text {LDWN } \rightarrow 68 \mathrm{~dB}}$ (feature No. 12);

- $\quad$ the distance of the nearest multi-family residential buildings from the railway area, marked as $\mathrm{L}_{\mathrm{MZW} \rightarrow \mathrm{TK}}$ (feature No. 13), from the axis of the outermost railway line, marked as $\mathrm{L}_{\mathrm{ZM} \rightarrow \mathrm{OT}}$ (feature No. 14);

the distance of the nearest one-family residential buildings from the railway area, marked as $\mathrm{L}_{\mathrm{ZJ} \rightarrow \mathrm{TK}}$ (feature No. 15), from the axis of the outermost railway line, marked as $L_{\mathrm{zJ} \rightarrow \mathrm{OT}}$ (feature No. 16);

areas of residential, one-family housing where children and adolescents stay permanently or temporarily, nursing homes and city hospitals located within the range of the $\mathrm{L}_{\mathrm{DWN}} 55 \mathrm{~dB}$ isophone, marked as $\mathrm{FTU}_{\mathrm{LWWN}_{\mathrm{N}} \mathrm{5 \textrm {dB }}}$ (feature No. 17), and located within the range of the $\mathrm{L}_{\mathrm{DWN}} 64 \mathrm{~dB}$ isophone, marked as $\mathrm{FTU}_{\mathrm{LDWN} \rightarrow 64 \mathrm{~dB}}$ (feature No. 18);

areas of multi-family and collective residences, farm buildings, recreation and leisure, residential and service areas located within the isophone $\mathrm{L}_{\mathrm{DWN}} 60 \mathrm{~dB}$, marked as $F T U_{\mathrm{LDWN} \rightarrow 60 \mathrm{~dB}}$ (feature No. 19), and located within the isophone $\mathrm{L}_{\mathrm{DWN}} 68 \mathrm{~dB}$, marked as FTU ${ }_{\text {LDWN } \rightarrow 68 \mathrm{~dB}}$ (feature No. 20);

areas of one-family housing connected with the permanent or temporary stay of children and youth, social care homes, city hospitals, multi-family and collective housing, farm buildings, recreation and leisure, residential and service buildings located within the isophone $L_{N} 50 \mathrm{~dB}$, marked as $\mathrm{FTU}_{\mathrm{LN} \rightarrow 50 \mathrm{~dB}}$ (feature No. 21), and located within range of isophone $L_{N} 59 \mathrm{~dB}$, marked as $\mathrm{FTU}_{\mathrm{LN} \rightarrow 59 \mathrm{~dB}}$ (feature No. 22).

The terms "day", "evening" and "night" are precisely defined in Directive 2002/49/EC of the European Parliament and Council of 25 June 2002. The definition determines "day" as between 6:00 to 18:00 (6:00AM to 6:00PM), "evening" from 18:00 to 22:00 (6:00PM to 10:00PM) and "night" from 22:00 to 6:00 (10:00PM to $6: 00 \mathrm{AM})$.

The most analytical task, RT3, utilises a proprietary set of indicators. The indicators were based on the Regulation of the Ministry of the Environment from 1 October 2012 concerning the permissible environmental noise levels according to art. $113 \S$ 1 of the Legal Act from 27 April 2001 - Environment Protection Law and the Regulation of the Ministry of the Environment from 14 June 2007 on permissible noise levels in the environment. We have proposed nine relevant indicators of so-called "Acoustic release" which are listed in Table 1.

\section{Results and discussion}

Isophones indicated on the acoustic maps as the result of interpolation of the $59 \mathrm{~dB}, 64 \mathrm{~dB}$ and $68 \mathrm{~dB}$ levels performed for the two periods: 2012 and 2017 (Table 2).

The calculated results show that the acoustic environment deteriorated in areas with a higher degree of urbanisation (Areas I and II). This deterioration was $5.39 \%$ in Area I and $9.81 \%$ in Area II in the night time. In the case of day-evening-night time, the relevant differences were smaller in Area I, $3 \%$ for $64 \mathrm{~dB}$ and $1.22 \%$ for $68 \mathrm{~dB}$, but much more significant in Area II, $11.28 \%$ for $64 \mathrm{~dB}$ and $7.61 \%$ for $68 \mathrm{~dB}$. The increasing area of the terrains 
Table 2. Areas and percentage shares of the terrains with exceeded noise levels caused by rail noise within the analysed boundaries according to acoustic maps from 2012 and 2017

\begin{tabular}{|c|c|c|c|c|c|}
\hline \multirow{3}{*}{ Isophone name } & \multirow{3}{*}{ DISTRICT } & \multicolumn{2}{|c|}{ Year 2012} & \multicolumn{2}{|c|}{ Year 2017} \\
\hline & & $\begin{array}{c}\text { Noise-endangered } \\
\text { area }\end{array}$ & $\begin{array}{c}\text { Terrain } \\
\text { percentage }\end{array}$ & $\begin{array}{c}\text { Noise-endangered } \\
\text { area }\end{array}$ & $\begin{array}{c}\text { Terrain } \\
\text { percentage }\end{array}$ \\
\hline & & [ha] & [\%] & [ha] & [\%] \\
\hline $\mathrm{L}_{\mathrm{N}} \rightarrow 59 \mathrm{~dB}$ & \multirow{3}{*}{$\begin{array}{l}\text { URSUS } \\
\text { (I) }\end{array}$} & 3.79 & 7.64 & 6.46 & 13.03 \\
\hline $\mathrm{L}_{\mathrm{DWN}} \rightarrow 64 \mathrm{~dB}$ & & 8.61 & 17.38 & 10.10 & 20.38 \\
\hline $\mathrm{L}_{\mathrm{DWN}} \rightarrow 68 \mathrm{~dB}$ & & 4.33 & 8.74 & 4.94 & 9.96 \\
\hline $\mathrm{L}_{\mathrm{N}} \rightarrow 59 \mathrm{~dB}$ & \multirow{3}{*}{$\begin{array}{c}\text { BIA } \mathrm{O} Ł E ̨ K A \\
\text { (II) }\end{array}$} & 4.55 & 6.93 & 10.99 & 16.74 \\
\hline $\mathrm{L}_{\mathrm{DWN}} \rightarrow 64 \mathrm{~dB}$ & & 6.68 & 10.18 & 14.09 & 21.46 \\
\hline $\mathrm{L}_{\mathrm{DWN}} \rightarrow 68 \mathrm{~dB}$ & & 2.71 & 4.13 & 7.71 & 11.74 \\
\hline $\mathrm{L}_{\mathrm{N}} \rightarrow 59 \mathrm{~dB}$ & \multirow{3}{*}{$\begin{array}{l}\text { URSYNÓW } \\
\text { (III) }\end{array}$} & 1.53 & 1.23 & 1.27 & 1.01 \\
\hline $\mathrm{L}_{\mathrm{DWN}} \rightarrow 64 \mathrm{~dB}$ & & 4.13 & 3.30 & 3.07 & 2.45 \\
\hline $\mathrm{L}_{\mathrm{DWN}} \rightarrow 68 \mathrm{~dB}$ & & 1.23 & 0.98 & 0.85 & 0.68 \\
\hline
\end{tabular}

Source: own elaboration

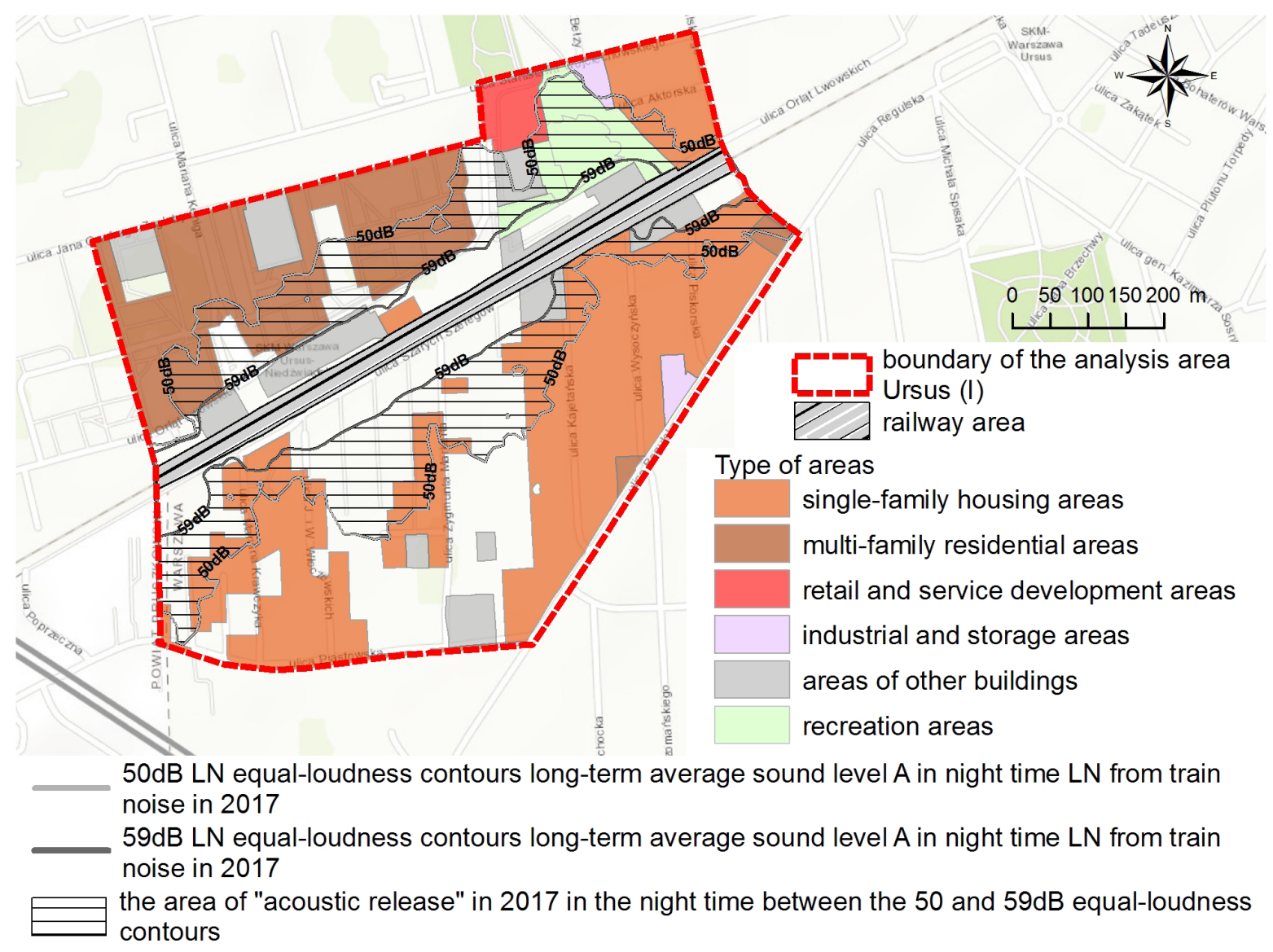

Figure 2. The area of "acoustic release" after changing the permissible sound levels in the night time in the area under analysis, Area 1 (Ursus)

Source: own elaboration 
MISCELLANEA GEOGRAPHICA - REGIONAL STUDIES ON DEVELOPMENT

Vol. $25 \cdot$ No. $3 \cdot 2021 \cdot$ pp. 155-168 • ISSN: 2084-6118 • DOI: 10.2478/mgrsd-2020-0062

Table 3. Features of sensitivity to noise within the boundaries of the analysed areas

\begin{tabular}{|c|c|c|c|c|c|}
\hline \multirow{2}{*}{ Feature No. } & \multirow{2}{*}{ Feature symbol } & \multirow{2}{*}{ Feature unit } & \multicolumn{3}{|c|}{ Feature value } \\
\hline & & & URSUS (I) & BIAŁOŁĘKA (II) & URSYNÓW (III) \\
\hline 1 & $F_{L N \rightarrow 50 d B}$ & $m^{2}$ & 208637 & 323317 & 120815 \\
\hline 2 & $F_{L N \rightarrow 59 d B}$ & $m^{2}$ & 64584 & 109909 & 12656 \\
\hline 3 & $\mathrm{~F}_{\text {LDWN } \rightarrow 55 \mathrm{~dB}}$ & $\mathrm{~m}^{2}$ & 254671 & 412510 & 197708 \\
\hline 4 & $\mathrm{~F}_{\mathrm{LDWN} \rightarrow 60 \mathrm{~dB}}$ & $\mathrm{~m}^{2}$ & 166783 & 242193 & 79266 \\
\hline 5 & $\mathrm{~F}_{\mathrm{LDWN} \rightarrow 64 \mathrm{~dB}}$ & $\mathrm{~m}^{2}$ & 101011 & 140877 & 30685 \\
\hline 6 & $F_{L D W N \rightarrow 68 d B}$ & $\mathrm{~m}^{2}$ & 49357 & 77107 & 8495 \\
\hline 7 & $\mathrm{LB}_{\mathrm{LN} \rightarrow 50 \mathrm{~dB}}$ & units & 138 & 163 & 12 \\
\hline 8 & $\mathrm{LB}_{\mathrm{LN} \rightarrow 59 \mathrm{~dB}}$ & units & 38 & 39 & 0 \\
\hline 9 & $\mathrm{LB}_{\text {LDWN } \rightarrow 55 \mathrm{~dB}}$ & units & 171 & 197 & 27 \\
\hline 10 & $\mathrm{LB}_{\text {LDWN } \rightarrow 60 \mathrm{~dB}}$ & units & 102 & 124 & 7 \\
\hline 11 & $\mathrm{LB}_{\mathrm{LDWN} \rightarrow 64 \mathrm{~dB}}$ & units & 55 & 59 & 1 \\
\hline 12 & $\mathrm{LB}_{\text {LDWN } \rightarrow 68 \mathrm{~dB}}$ & units & 33 & 17 & 0 \\
\hline 13 & $\mathrm{~L}_{\mathrm{MZW} \rightarrow \mathrm{TK}}$ & $\mathrm{m}$ & 64 & - & - \\
\hline 14 & $\mathrm{~L}_{\mathrm{ZM} \rightarrow \mathrm{OT}}$ & $\mathrm{m}$ & 75 & - & - \\
\hline 15 & $\mathrm{~L}_{\mathrm{ZJ} \rightarrow \mathrm{TK}}$ & $\mathrm{m}$ & 11 & 22 & 18 \\
\hline 16 & $\mathrm{~L}_{\mathrm{ZJ} \rightarrow \mathrm{OT}}$ & $\mathrm{m}$ & 24 & 34 & 24 \\
\hline 17 & $F T U_{\text {LDWN } \rightarrow 55 \mathrm{~dB}}$ & $\mathrm{~m}^{2}$ & 58305 & 143670 & 17326 \\
\hline 18 & $\mathrm{FTU}_{\mathrm{LDWN} \rightarrow 64 \mathrm{~dB}}$ & $\mathrm{~m}^{2}$ & 1643 & 48851 & 1096 \\
\hline 19 & $\mathrm{FTU}_{\mathrm{LDWN} \rightarrow 60 \mathrm{~dB}}$ & $\mathrm{~m}^{2}$ & 61237 & 99139 & 4157 \\
\hline 20 & FTU $_{\text {LDWN } \rightarrow 68 \mathrm{~dB}}$ & $m^{2}$ & 1643 & 25607 & 255 \\
\hline 21 & $\mathrm{FTU}_{\mathrm{LN} \rightarrow 50 \mathrm{~dB}}$ & $\mathrm{~m}^{2}$ & 91538 & 134242 & 8531 \\
\hline 22 & $\mathrm{FTU}_{\mathrm{LN} \rightarrow 59 \mathrm{~dB}}$ & $\mathrm{~m}^{2}$ & 6550 & 39126 & 351 \\
\hline
\end{tabular}

indicators that were in force before 2012

- new obligatory indicators

Source: own elaboration

Table 4. The values of acoustic indicators within the analysed areas

\begin{tabular}{|c|c|c|c|}
\hline \multirow[b]{2}{*}{ Feature symbol } & \multicolumn{3}{|c|}{ Feature value } \\
\hline & $\begin{array}{l}\text { URSUS } \\
\text { (Area I) }\end{array}$ & $\begin{array}{l}\text { BIAŁOŁĘKA } \\
\text { (Area II) }\end{array}$ & $\begin{array}{l}\text { URSYNÓW } \\
\text { (Area III) }\end{array}$ \\
\hline$W_{L N}$ & 0.38 & 0.66 & 0.90 \\
\hline $\mathrm{W}_{1} \mathrm{UA}_{\text {LDWN }}$ & 0.60 & 0.66 & 0.98 \\
\hline $\mathrm{W}_{2} \mathrm{UA}_{\text {LDWN }}$ & 0.70 & 0.68 & 0.89 \\
\hline WUFA $_{L N}$ & 0.93 & 0.71 & 0.96 \\
\hline $\mathrm{W}_{1} \mathrm{UFA}_{\text {LDWN }}$ & 0.97 & 0.66 & 0.64 \\
\hline $\mathrm{W}_{2} \mathrm{UFA}_{\text {LDWN }}$ & 0.97 & 0.74 & 0.94 \\
\hline$W_{B A} A_{L N}$ & 0.72 & 0.76 & 1.00 \\
\hline $\mathrm{W}_{1} \mathrm{BA}_{\mathrm{LDWN}}$ & 0.68 & 0.71 & 0.96 \\
\hline $\mathrm{W}_{2} \mathrm{BA}_{\mathrm{LDWN}}$ & 0.67 & 0.86 & 1.00 \\
\hline
\end{tabular}

Source: own elaboration 


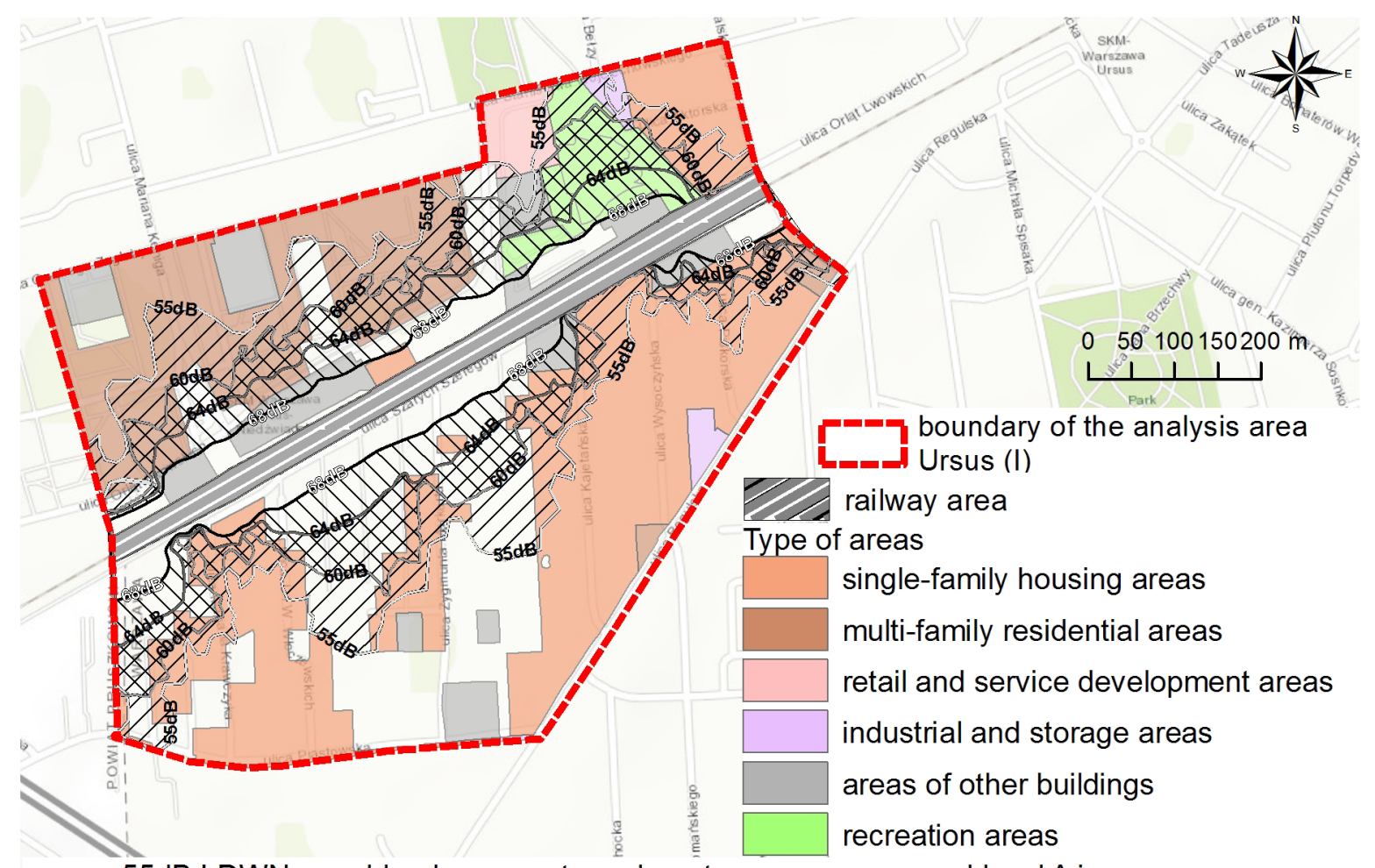

$55 \mathrm{~dB}$ LDWN equal-loudness contours long-term average sound level $\mathrm{A}$ in day-evening-night time LDWN from train noise in 2017

$64 \mathrm{~dB}$ LDWN equal-loudness contours long-term average sound level $A$ in day-evening-night time LDWN from train noise in 2017 68dB LDWN equal-loudness contours long-term average sound level $A$ in day-evening-night time LDWN from train noise in 2017

$60 \mathrm{~dB}$ LDWN equal-loudness contours long-term average sound level $A$ in day-evening-night time LDWN from train noise in 2017

the area of "acoustic release" in 2017 in the day-evening-night time between the 55 and $64 \mathrm{~dB}$ equal-loudness contours the area of "acoustic release" in 2017 in the day-evening-night time between the 60 and $68 \mathrm{~dB}$ equal-loudness contours

Figure 3. The area of "acoustic release" after changing the permissible sound levels in the day-evening-night time in the area under analysis, Area 1 (Ursus)

Source: own elaboration

exposed to railway noise may indicate a deterioration in the technical condition of the rails and rolling stock as well as a failure to install noise-reduction elements as part of the spatial development which took place. In the case of the least urbanised area located within Area III, the acoustic conditions over the five years remained at similar levels and even slightly improved by $0.22 \%$ at night (at $59 \mathrm{~dB}$ ) and $0.85 \%($ at $64 \mathrm{~dB}$ ), and by $0,3 \%$ (at $68 \mathrm{~dB}$ ) for day/evening/night time.

The results concerning the spatial and construction features resulting from the risk of a railway noise are given in Table 3.

The values of the acoustic and spatial indicators for the analysed areas are presented in Table 4.

Analysing the above values, one can conclude that permissible levels of railway noise influence the interpretation of acoustic hazard in urbanised areas. Based on the results shown in Table 4, the amendment to the legal regulations has reduced the size of areas considered as noise-sensitive by $38 \%$ within Area I (Ursus) (Fig. 2), 66\% in Area II (Białołęka) (Fig. 4) and by as much as $90 \%$ in Area III (Ursynów) (Fig. 6). The amendment directly led to a fall in the number of buildings exposed to noise pollution and their inhabitants. In Area I, one can observe a fall of $72 \%$; in Area II $-76 \%$, and in Area III the potential threat was entirely eliminated. The increase in the permissible noise standards LDWN for the day-evening-night time, from $55 \mathrm{~dB}$ to $64 \mathrm{~dB}$, resulted in a reduction of the area considered to be threatened by railway noise by $60 \%$ in Area I (Fig. 3), $66 \%$ in Area II (Fig. 5) and as much as $98 \%$ in Area III (Fig. 7). Similarly, it reduced the number of buildings considered to be threatened by $68 \%$ in Area I, $71 \%$ in Area II and as much as $96 \%$ in Area III. The changes looked even more unfavourable where LDWN noise levels were increased from $60 \mathrm{~dB}$ to $68 \mathrm{~dB}$. The areas at risk in Area I (Ursus) were reduced by $70 \%$ (Fig. 3), in Area II 


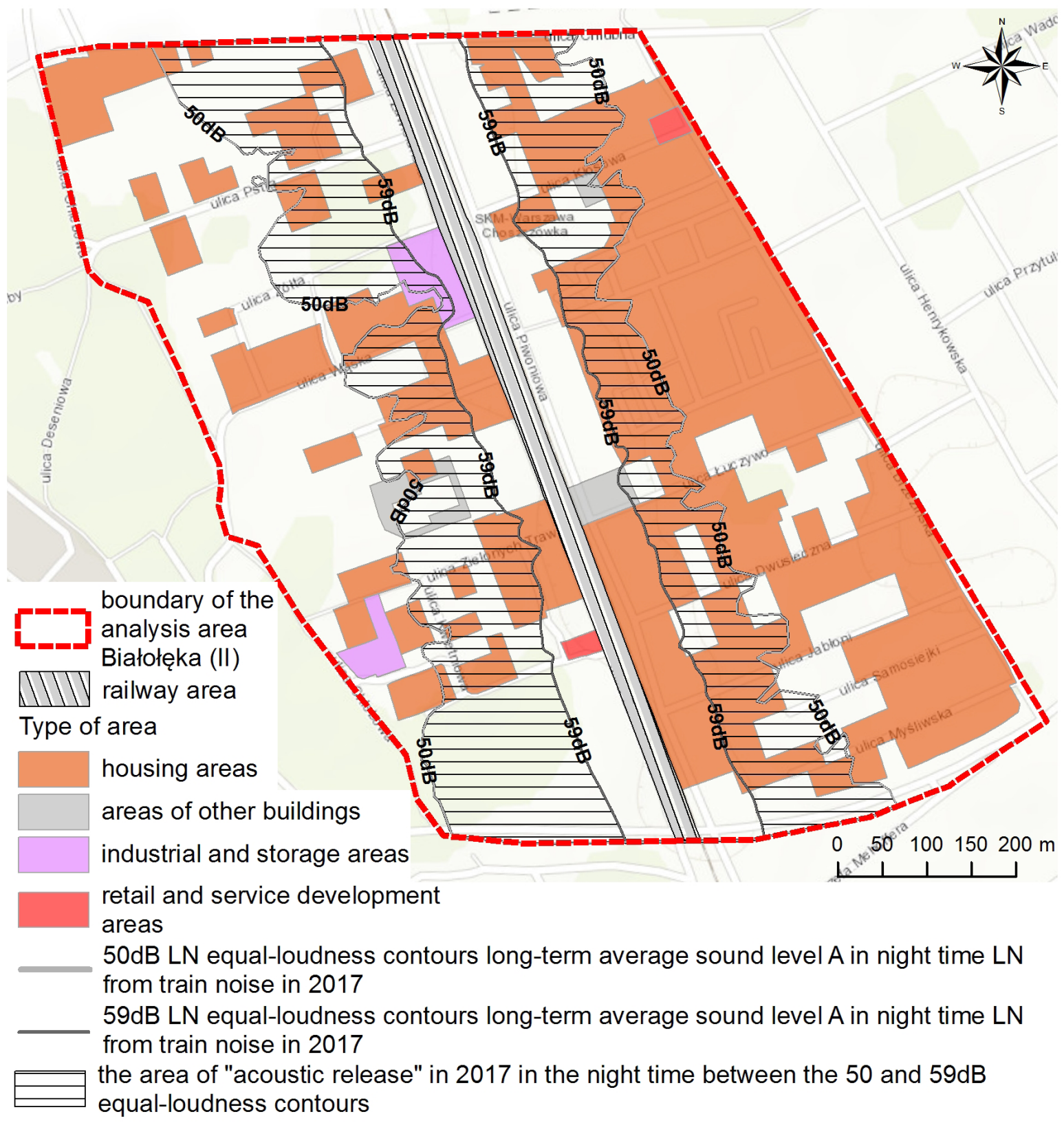

Figure 4. The area of "acoustic release" after changing the permissible sound levels in the night time in the area under analysis, Area II (Białołęka)

Source: own elaboration

(Białołęka) by $68 \%$ (Fig. 5), and in Area III (Ursynów) by $89 \%$ (Fig. 7). For the 60dB LDWN, this was, in turn, $67 \%, 86 \%$ and $100 \%$.

The indicators of functional and acoustic release are more objective because they refer only to areas that are considered noise-sensitive according to the legal regulation. Regarding single-family housing areas, buildings related to the permanent or temporary dwelling of children and youth, social care homes and city hospitals, the change of the permissible value of the LDWN parameter from $55 \mathrm{~dB}$ to $64 \mathrm{~dB}$ resulted in the reduction of the size of the hazardous areas by $97 \%$ in Area I, $66 \%$ in Area II and by $64 \%$ in Area III. For multi-family and collective housing, farm buildings, recreational, residential and service buildings, the amendment to the legal regulation resulted in a decrease in the area affected by railway noise of $97 \%$ in Area I, $74 \%$ in Area II and $94 \%$ in Area III. In the context of night time, the change in the permissible noise level from $50 \mathrm{~dB}$ to $59 \mathrm{~dB}$ led to a reduction in the size of noise-sensitive areas of $93 \%$ in Area I, $71 \%$ in Area II and $96 \%$ in Area III.

\section{Conclusions}

The studies performed made it possible to solve the research tasks (RT's) presented in the "Research problem" section. The performed analysis confirms that the acoustic climate in the 
study areas has deteriorated over the five years between 2012 and 2017 (RT1). In the districts of Ursus and Białołęka (Areas I

and II), the surface area of the isophone ranges $L_{\text {mN }} 68, L_{\text {min }} 64$, $\mathrm{L}_{\mathrm{DWN}} 60, \mathrm{~L}_{\mathrm{DWN}} 55, \mathrm{~L}_{\mathrm{N}} 50$ and $\mathrm{L}_{\mathrm{N}} 59$ increased between 2012 and

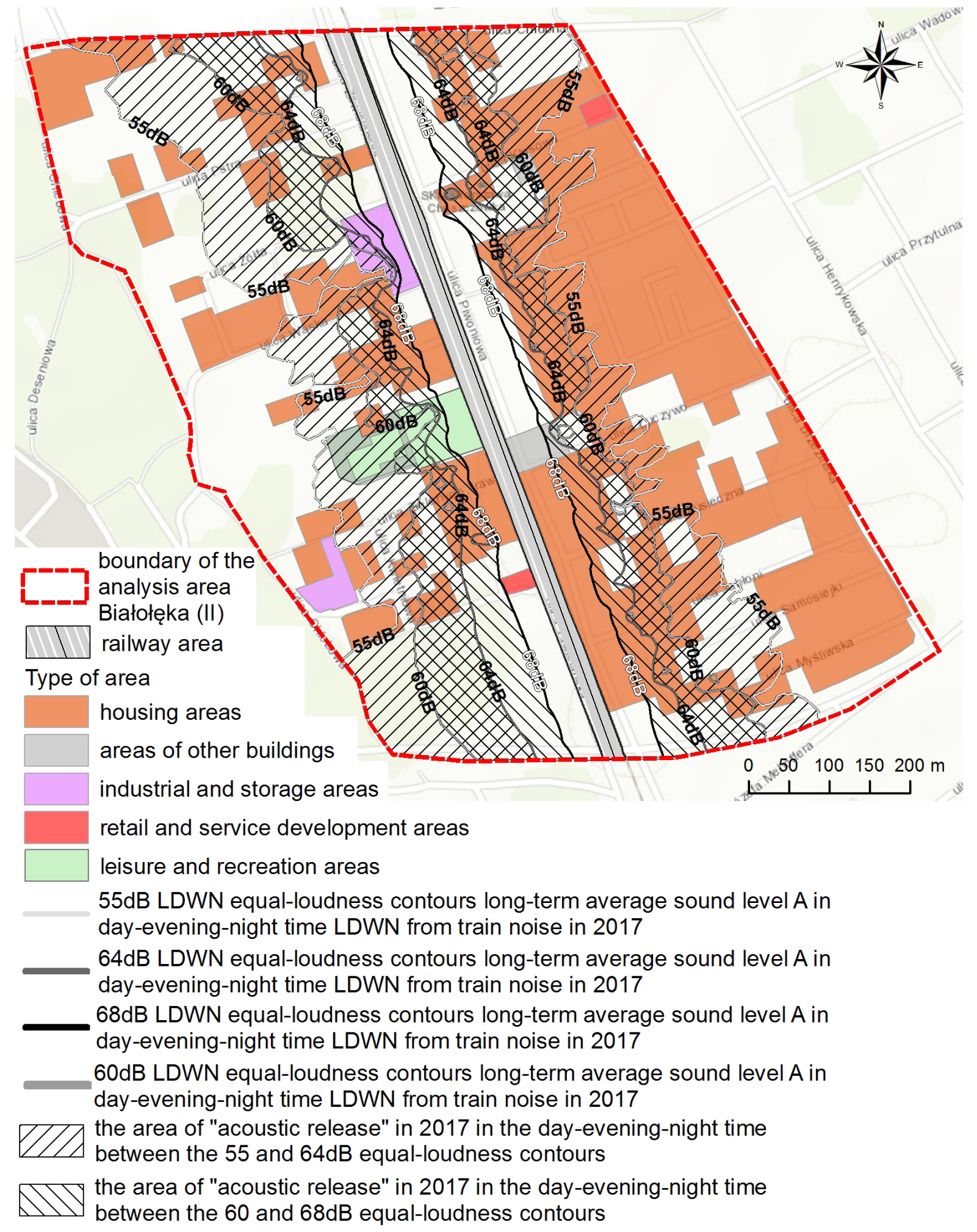

Figure 5. The area of "acoustic release" when changing the permissible sound levels in the day-evening-night time in the area under analysis, Area II (Białołęka)

Source: own elaboration 


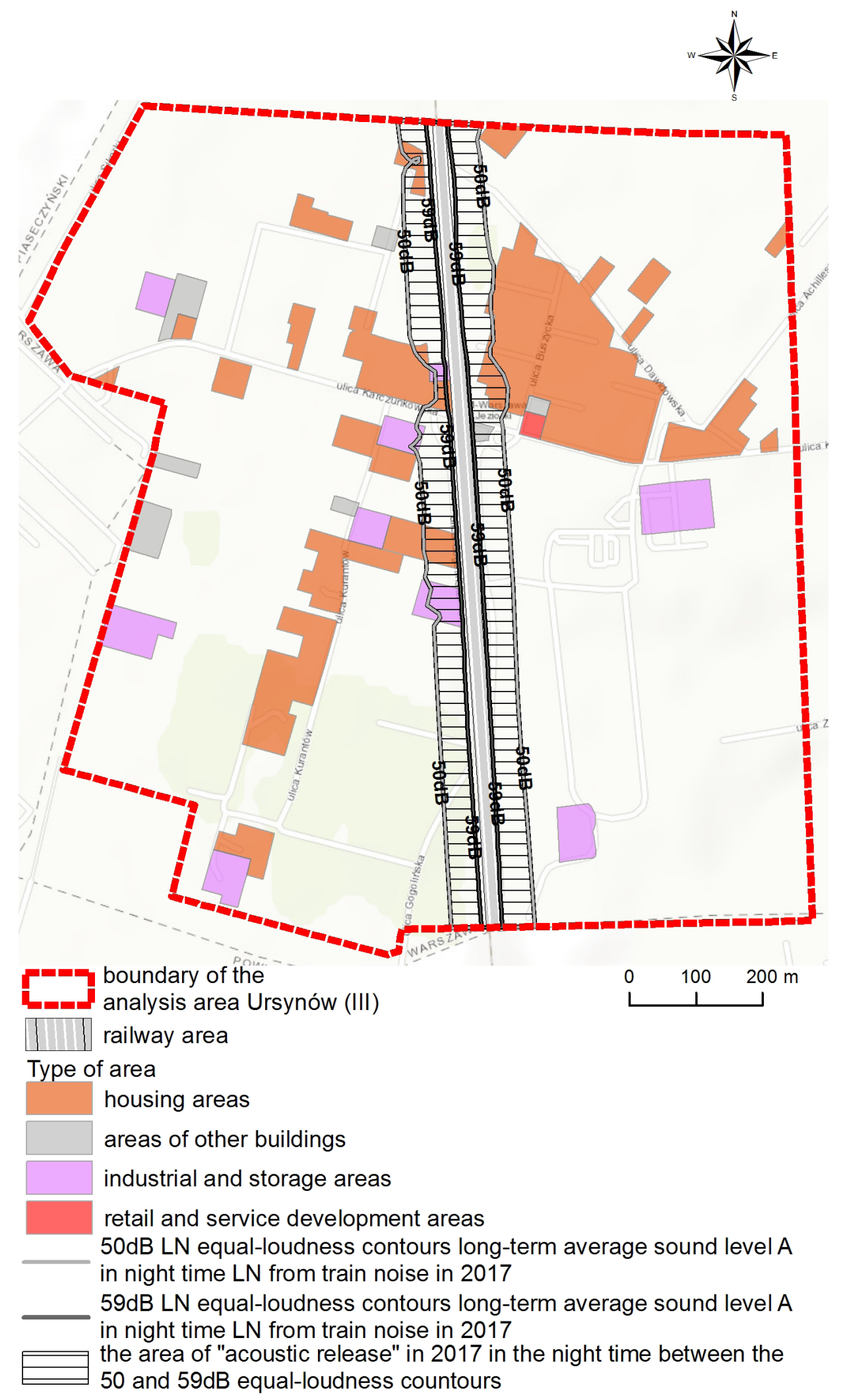

Figure 6. The area of "acoustic release" after changing the permissible sound levels in the night time in the area under analysis, Area III (Ursynów)

Source: own elaboration 


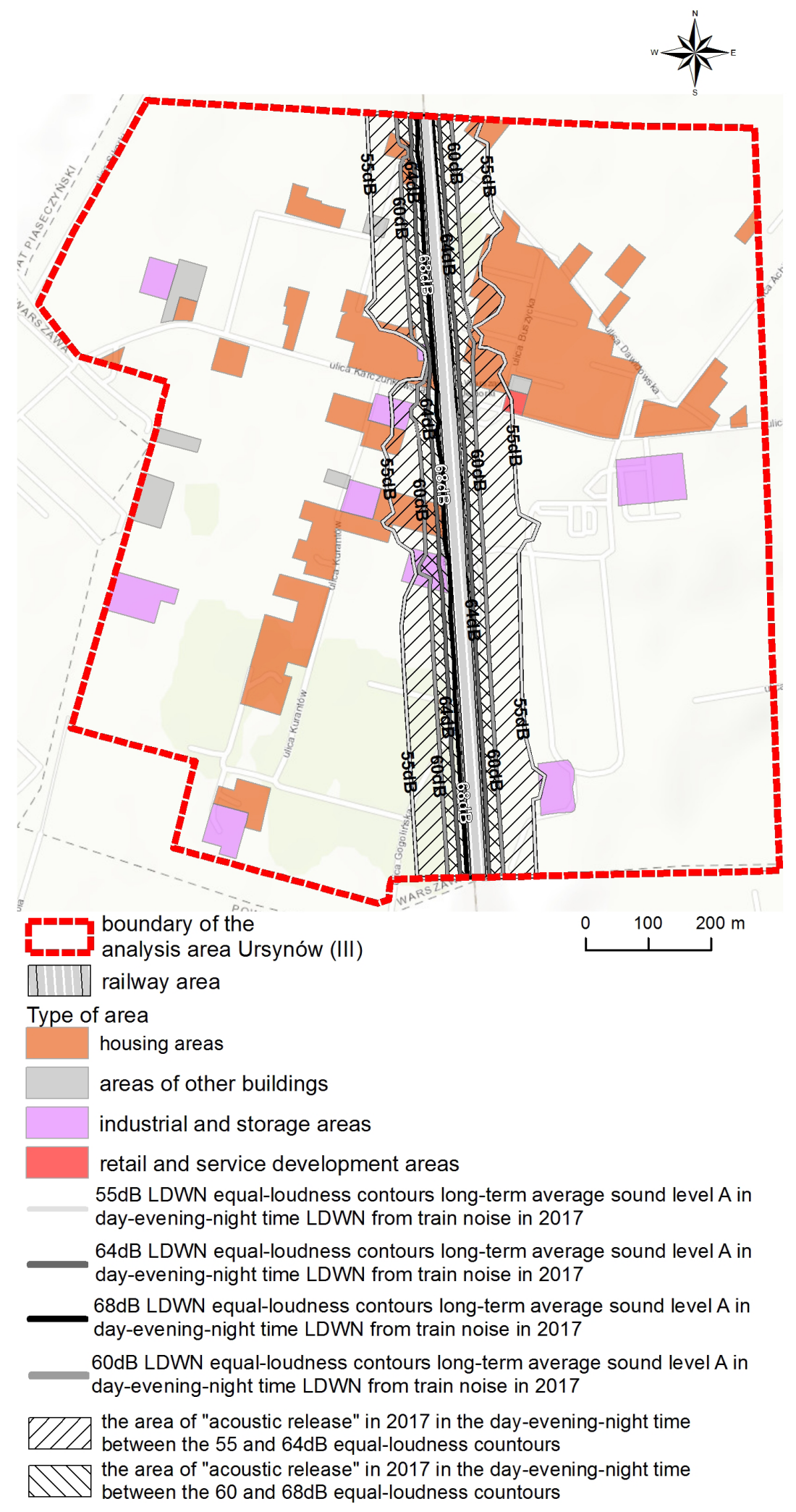

Figure 7. The area of "acoustic release" when changing the permissible sound levels in the day-evening-night time in the area under analysis, Area III (Ursynów)

Source: own elaboration 
2017. Meanwhile, the acoustic climate in Area III (Ursynów) remained relatively stable.

The introduction of amendments to the legal regulation on permissible noise levels has led to significant release of land dedicated to future investments without requiring additional expenditure to reduce excessive noise. Increasing the allowable railway noise indicators $L N$ and LDWN has meant that, in areas with high and medium degrees of urbanisation, the amount of land with functions sensitive to noise fell by between $40 \%$ to $70 \%$ and, in less urbanised areas, by as much as $90-100 \%$ (RT2). It follows that the calculations for distances to buildings considered to be exposed to noise do not entirely result from acoustic hazard, but are rather defined by the regulations of the Act on the Railway Transport (2003)

Increasing the $\mathrm{LN}$ from $50 \mathrm{~dB}$ to $59 \mathrm{~dB}$ and the LDWN from $55 \mathrm{~dB}$ to $64 \mathrm{~dB}$ (night time) and from $60 \mathrm{~dB}$ to $68 \mathrm{~dB}$ (day-night) is beneficial for investors and contractors who can develop areas close to railways without investing in additional noise reduction measures. On the other hand, increasing permissible noise levels by as much as $9 \mathrm{~dB}$ should be considered very shocking and negative for the health of future residents. They will probably not be satisfied with the acoustic climate despite the fact that the applicable standards theoretically do not exceed permissible noise levels in areas near railway lines (RT3).

This conclusion clearly shows that the increase in permissible noise levels was driven more by industrial and economic factors than health and social concerns. By deciding to increase permissible noise levels in the environment, it is a challenge to ensure appropriate, balanced spatial planning of urban areas in the proximity of railway lines. Although these analyses are based on the example of Warsaw, the situation could be generalised and applied to similar places where land is developed in the proximity of railways.

\section{ORCID}

Konrad Podawca (iD https://orcid.org/0000-0001-5261-6657

Krzysztof Karsznia (D) https://orcid.org/0000-0002-0262-6651

Kamil Jewuła (iD https://orcid.org/0000-0001-9874-9383

\section{References}

Babisch, W, Neuhauser, H \& Thamm M 2009, 'Blood pressure of 8-14-year-old children in relation to traffic noise at home - Results of the German Environmental Survey for Children (GerES IV)', Science of the Total Environment, vol. 407, pp. 5839-5843.

Barregard, L \& Stansfeld, S 2014, 'Medication use as an outcome variable in environmental (noise) epidemiology', Scandinavian Journal of Work, Environment and Health, vol. 40, no. 3, pp. 211-213

Beim, M \& Tölle, A 2008a, 'Motywacje migracji rezydencjalnych w obszarze aglomeracji Poznańskiej' ['Motivations for resident migrations within the area of Poznań Agglomeration'] in Powiat poznański. Jakość przestrzeni i jakość życia [District of Poznań. The quality of space and life], ed. T Kaczmarek \& A Mizgajski, Bogucki Wydawnictwo Naukowe, Poznań, pp. 121-138.

Beim, M \& Tölle, A 2008b, 'Segregationsprozesse zwischen altbauverfall und suburbanisierung: Das beispiel Posen ['Segregation processes between declining older buildings and suburbanisation - case study Posen'], The Planning Review, vol. 44, no. 174, pp. 51-65.

Brade, I \& Rudolph, R 2004, 'Moscow, the global city? The position of the Russian capital within the European system of metropolitan areas', Area, vol. 36, no. 1, pp. 69-80.

Clausen, U, Doll, C, Franklin, F, Franklin, G, Heinrichmeyer, $H$ Kochsiek, J, Rothengatter, W \& Sieber, N 2012, 'Reducing railway noise pollution', Transport and Tourism, Study, no. IP/B/TRAN/FWC/2010-006/LOT4/C1/SC2, pp. 3-6.

Commission Implementing Regulation (EU) 2015/429 of 13 March 2015 setting out the modalities to be followed for the application of the charging for the cost of noise effects Text with EEA relevance. Available from: < http://data.europa.eu/ eli/reg impl/2015/429/oj>. [05.05.2021].

Commission Implementing Regulation (EU) 2019/774 of 16 May 2019 amending Regulation (EU) No 1304/2014 as regards application of the technical specification for interoperability relating to the subsystem 'rolling stock - noise' to the existing freight wagons (Text with EEA relevance). Available from: <http://data.europa.eu/eli/reg_impl/2019/774/oj> [5.05.2021]

Degórska, B 2012, 'Problemy planowania struktur przyrodniczych Obszaru Metropolitalnego Warszawy związane z żywiołowa urbanizacją przestrzeni. Mazowsze' ['Problems of natural structure planning within Warsaw Metropolitan Area regarding vital urbanisation of space. Masovia'], Studia Regionalne, no. 10/2012, pp. 89-106.

Deja, A\& Kopeć, A2016, 'Analiza natężenia hałasu generowanego przez transport kolejowy w wybranym punkcie Aglomeracji Szczecińskiej' ['Analyse of the intensity of noise emmited by the railway transport in selected place of Szczecin Agglomeration'], Autobusy: technika, eksploatacja, systemy transportowe, vol.17, no 12, pp. 117-121.

Di Zio, S, Montanari, A \& Staniscia, B 2010, 'Simulation of urban development in the City of Rome', The Journal of transport and land use, Vol. 3, no. 2, pp. 85-105.

Directive 2002/49/EC of the European Parliament and of the Council of 25 June 2002 relating to the assessment and management of environmental noise - Declaration by the Commission in the Conciliation Committee on the Directive relating to the assessment and management of environmental noise. Available from: <http://data.europa.eu/ eli/dir/2002/49/oj>. [06.05.2021].

Felcyn, J, Preis, A, Kokowski, P \& Gałuszka, M 2018, 'A comparison of noise mapping data and 'people's assessment of annoyance: How can noise action plans be improved?', Transportation Research Part D, vol. 63, pp. 72-120.

Halonen, JI, Vahtera, J \& Stansfeld, S 2012, 'Associations between nighttime traffic noise and sleep: The finnish public sector study', Environmental Health Perspectives, vol. 120, pp. 1391-1396.

Huang, X, Yang, J, Güneralp, B \& Burris, M 2017, 'U.S. metropolitan spatial structure evolution: Investigating spatial patterns of employment growth from 2000 to 2010', Urban Sciences, vol. 1, no. 28.

Jarup, L, Babisch, W \& Houthuijs, D 2008, 'Hypertension and exposure to noise near airports: the HYENA study', Environmental Health Perspectives, vol. 116, pp. 329-333.

Makosz, E 2015, 'Ograniczenia środowiskowe w planowaniu przestrzennym związane z istnieniem linii kolejowej - wpływ linii kolejowej na sposób zagospodarowania nieruchomości' ['Environmental limitations in spatial planning tied with the existence of a railway line - the influence of a railway line on the way of real estate development'], Conference Proceedings, Planowanie przestrzenne na terenach kolejowych [Land development on railway areas], Warsaw, 13 October 2015 
Miedema, HME \& Oudshoorn, CGM 2001, 'Annoyance from transportation noise: relationships with exposure metrics DNL and DENL and their confidence intervals', Environmental Health Perspectives, vol. 109, no. 4, pp. 409-416.

Night Noise Guidelines for Europe WHO 2009. Available from:<https://www.euro.who.int/__data/assets/pdf_ file/0017/43316/E92845.pdf>. [14 January 2021].

Origins and aims of the GEOPORTAL 2 project. Available from:<https://www.geoportal.gov.pl/o-geoportalu/ informacje-o-projekcie>. [13 January 2021].

Passchier-Vermeer, W \& Passchier, WF 2000, 'Noise exposure and public health', Environmental Health Perspectives, vol. 108, no. 1, pp. 123-131.

Pawlas, K 2015, 'Hałas jako czynnik zanieczyszczający środowisko - aspekty medyczne' ['The noise as an environment polluting factor - medical aspects'], Medycyna Środowiskowa, vol. 18, no. 4, pp. 49-56.

Pedersen, E \& Waye, KP 2007, 'Wind turbine noise, annoyance and self-reported health and well-being in different living environments', Occupational and Environmental Medicine, vol. 64 , pp. $480-486$.

Podawca, K, Karsznia, K \& Pawłat-Zawrzykraj, A 2019, 'The assessment of the suburbanisation degree of Warsaw Functional Area using changes of the land development structure', Miscellanea Geographica, vol. 23, no. 4, pp. 215-224.

Podawca, K \& Mrozik, K 2019, 'Diversifying of the degree of implementation of planning and investment processes in the communes of the Warsaw Functional Urban Area', Scientific Review - Engineering and Environmental Sciences, vol. 28, no. 1 , pp. 105-117.

Podawca, K \& Staniszewski, R 2019, 'Impact of changes of the permissible railway noise levels on possibilities of spatial management in urban areas', Annual Set - The Environment Protection, vol. 21, no. 2, pp. 1378-1392.

Podawca, K 2014, 'Hałas drogowy jako ograniczenie możliwości zagospodarowania przestrzennego na wybranych przykładach' ['Road noise as the limitation of land development on selected examples'], Problemy Rozwoju Miast, vol. 11, no. 1, pp. 5-19.

Podawca, K \& Karpiński, A, 2021, 'Analysis of spatial development possibilities of properties endangered by road noise in the context of permissible LN and LDWN indicators', Journal of Ecological Engineering, vol. 22, no. 5, pp. 238-248.

Popławska, K, Fijałkowska, A \& Osińska-Skotak, K 2012, 'Wykorzystanie technologii GIS do wyznaczania stref zagrożenia hałasem komunikacyjnym' ['Using GIS technology in the determination of transportation noise pollution'], Archiwum Fotogrametrii, Kartografii i Teledetekcji, vol. 23, pp. 327-336.

Preis, A, Felcyn, J, Kokowski, P, Gałuszka, M \& Libiszewski, P 2019, 'Estimating the population exposed to transportation noise: a case study on Poznań 'City', Vibrations in Physical Systems, vol. 30, no. 1, no. 2019/120, pp. 1-8.

Profaska, M, Korban, Z \& Kernert, R 2012, 'Sample surveys of nuisance of noise emissions from communication pathway', Rocznik Ochrona Środowiska, vol. 14, pp. 800-813.

Roca, J, Burns, MC \& Carreras, JM 2004, 'Monitoring Urban Sprawl around Barcelona's Metropolitan Area with the aid of satellite imagery', 20 th ISPRS Congress, Istanbul, Turkey, 12-23 July 2004. Available from: <https://pdfs. semanticscholar.org/1a99/4875b350753c4f81d9c33c98180 531af6ce0.pdf>. [14 January 2021].

Rozporządzenie Ministra Ochrony Środowiska z dnia 14 czerwca 2007 r. w sprawie dopuszczalnych poziomów hałasu w środowisku [Regulation of the Minister of the Environment
Protection of 14 June 2007 on permissible noiselevels in the environment], Dz.U. Nr 120 from 5 July 2007, pos. 826. Available from: <http://isap.sejm.gov.pl/isap.nsf/DocDetails. xsp?id=wdu20071200826>. [14.01.2021].

Rozporządzenie Ministra Środowiska z dnia 1 października 2012 r. zmieniające rozporządzenie $w$ sprawie dopuszczalnych poziomów hałasu w środowisku [Regulation of the Minister of the Environment Protection ammending the regultion of 14 June 2007 on permissible noiselevels in the environment], Dz.U. 2012, pos. 1109. Available from: <http://isap.sejm. gov.pl/isap.nsf/DocDetails.xsp?id=WDU20120001109>. [14.01.2021].

Ryś, R 2015, 'Znaczenie terenów kolejowych w planowaniu przestrzennym - wizja MliR w zakresie terenów kolejowych i ich znaczenie w Krajowej Polityce Miejskiej' ['Importance of the railway areas in spatial planning - the vision of MliR in terms of railway areas and their importance for National Urban Policy'], Conferene proceedings 'Spatial planning on railway areas', Warsaw, 13 October 2015. Available from: <https://docplayer. pl/14070751-Planowanie-przestrzenne-na-terenach-kolej https://docplayer.pl/14070751-Planowanie-przestrzenne-naterenach-kolejowych.html> [14 January 2021].

Simons, RA \& El Jaouhari, A 2004, 'The effect of freight railroad tracks and train activity on residential property 'values', Appraisal Journal, vol. 72, no. 3, pp. 223-233.

Sobotova, L, Jurkovicova, J \& Stefanikova, Z 2010, 'Community response to environmental noise and impact on cardiovascular risk score', Science Total Environment, vol. 408, pp. 1264-1270.

Spórna, T 2018, 'The suburbanisation process in a depopulation context in the Katowice conurbation', Poland. Environmental \& Socio-economic Studies, vol. 6, no. 1, pp. 57-72.

Statistical Office in Warszawa 2021. Official website. Available from:\&lt; https://warszawa.stat.gov.pl/edukacjastatystyczna/. [14 January 2021].

Statistical Office in Warszawa 2021. Official website. Available from: <https://warszawa.stat.gov.pl/en/>. [9 February 2021].

Śleszyński, P (ed.) 2012, 'Warszawa i obszar metropolitalny Warszawy a rozwój Mazowsza' ['Warsaw and its metropolitan area versus the development of Masovia'], Seria Trendy Rozwojowe Mazowsza, no. 8, Mazowieckie Biuro Planowania Regionalnego w Warszawie, Warszawa, pp. 1- 160 .

Ustawa z dnia 27 kwietnia 2001 r. Prawo ochrony środowiska (tekst jednolity, Dz.U. 2018 poz. 779) [Legal act from 27 April 2001, Environment protection law (unified text, Dz.U. 2018 pos. 779)]. Available from: <http://isap.sejm.gov.pl/isap.nsf/ DocDetails.xsp?id=WDU20180000799>. [14 January 2021].

Ustawa z dnia 27 marca 2003 r. o planowaniu i zagospodarowaniu przestrzennym (tekst jednolity Dz. U. z 2017 r. poz. 1073) [Legal act from 27 March 2003 on spatial planning and land development (unified text, Dz.U. 2017 pos. 1073)]. Available from: <http://isap.sejm.gov.pl/isap.nsf/DocDetails. xsp?id=WDU20030800717>. [14 January 2021].

Ustawa z dnia 28 marca 2003 r. o transporcie kolejowym (tekst jednolity Dz. U. z 2017 r. poz. 2117) [Legal act from 28 March 2003 on the railway transport, (unified text, Dz.U. 2017 pos. 2117)]. Available from: <https://isap.sejm.gov.pl/isap.nsf/ DocDetails.xsp?id=WDU20030860789 > . [14 January 2021].

Von der Dunk, A 2011, 'Spatially explicit analysis of land-use conflicts in Northern Switzerland: new approaches for investigating a complex 'phenomenon', Doctoral Thesis, ETH Zurich, Paper I, Conflict typology, Landscape and Urban Planning, vol. 101, pp. 149-156.

Vogiatzis, K \& Remy, N 2017, 'Soundscape design guidelines through noise mapping methodologies: An application to 
medium urban 'agglomerations', Noise Mapping, vol. 4, pp. $1-19$.

Woo, M 2014, 'Urban containment policies and urban growth', International Journal of Urban Sciences, vol. 18, no. 3, pp. 309-326.

World Urbanization Prospects: The 2018 Revision 2019, United Nations, Department of Economic and Social Affairs, New York. Available from:<https://www.un.org/development/ desa/publications/2018-revision-of-world-urbanizationprospects.html>. [14 January 2021].

Wrótny, M \& Bohatkiewicz, J 2020 'Impact of railway noise on people based on strategic acoustic 'maps', Sustainability, vol. 12, no. 5637.

Zagubień, A \& Wolniewicz, K 2017, 'Domowe źródła hałasu niskoczęstotliwościowego' ['Home sources of the lowfrequency noise'], Rocznik Ochrona Środowiska, vol. 19, pp. 682- 693.

Zwierzchowska, I 2017, 'Urban ecosystem services - assessment of potential at the different spatial scale: an example of Poznan', Journal of the Polish Association of Environmental and Resource Economists, vol. 1, no. 60, pp. 207- 225. 